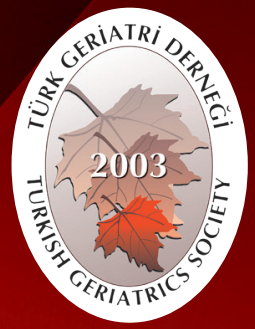

Turkish Journal of Geriatrics DOI: $10.31086 /$ tigeri.2018.61 2018;21 (4):550-556

- Özgür ÖNAL

- Elif DURUKAN ${ }^{2}$

CORRESPONDANCE

Özgür ÖNAL

Süleyman Demirel University, Faculty of Medicine, Department of Public Health, Isparta, Turkey

\section{Phone: 02462113714}

e-mail: ozgurional@hotmail.com

Received: 27/08/2018

Accepted: 05/12/2018

Süleyman Demirel University, Faculty of Medicine, Department of Public Health, Isparta, Turkey

Başkent University, Faculty of Medicine, Department of Public Health, Ankara, Turkey

\section{FREQUENCY OF POLYPHARMACY AND RISK FACTORS IN THE ELDERLYIN BURDUR}

\section{Abstract}

Introduction: Polypharmacy is common among the elderly. This study aimed to determine the frequency of polypharmacy and the risk factors in the elderly.

Materials and Method: This cross-sectional study will be analysed in three stages (polypharmacy, drug characteristics and drug interaction). Herein, the first stage (polypharmacy) was conducted at Burdur city centre and the connected villages. A total of 400 of 11,360 subjects aged $\geq 65$ years who were registered with family physicians in Burdur city centre were selected using a systematic sampling method. A questionnaire of 30 questions about socio-demographic variables and rational drug use was distributed among the subjects. Subsequently, the subjects were asked to bring their own drugs from home that they were actively using or not currently using, and their drug-using behaviour was analysed via specific questions.

Results: The average number of different drugs possessed by the subjects at home was approximately $6(5.95 \pm 4.30)$. A total of $64.9 \%$ of the drugs were used regularly, $21.3 \%$ were used occasionally and $13.8 \%$ were previously used but not currently used. The median number \pm standard deviation of the drugs that were used regularly, used occasionally and previously used but not currently used was $3.86 \pm 3.36,1.27 \pm 1.75$ and $0.82 \pm 1.82$, respectively. According to the results of multivariate analysis, the presence of diabetes, hypertension, respiratory system or cardiovascular (except hypertension) diseases, visual impairment or hearing disorders significantly increased the total drug use $(p<0.05)$

Conclusion: Chronic diseases and living in the city centre are the main risk factors leading to polypharmacy. Therefore, interventions must be undertaken by monitoring and reducing chronic diseases and providing training on rational drug use in the provincial centres.

Key words: Polypharmacy; Aged; Chronic disease

ARAŞTIRMA

\section{BURDUR ILINDE YAŞAYAN YAŞLILARDA POLIFARMASI SIKLIĞI VE POLIFARMASIYYI ETKILEYEN ETMENLER}

\section{$\ddot{O}_{z}$}

Giriş: Polifarmasi yaşılıkta çok sık görülür. Bu araştırmada Burdur ilinde yaşayan yaşı bireylerde polifarmasi sıklığı ve neden olan risk faktörlerinin incelenmesi amaçlanmıştır.

Gereç ve Yöntem: Kesitsel tipte planlanan polifarmasi, ilaçların özellikleri, ilaç etkileşimi aşamalı bir çalışmanın birinci aşamasının (polifarmasi) yer aldığı bu araştırma, Burdur ili merkezi ve merkeze bağlı köylerde gerçekleştirildi. Burdur ili merkezde aile hekimlerine kayıtlı 65 yaş ve üzeri 11360 kişiden 400'ü sistematik örneklem yöntemiyle seçilmiştir. Kişilere sosyodemografik değişkenler ve akılcı ilaç tutumuna yönelik 30 soruluk anket uygulandı ve ikinci aşamada kişilerin evlerinde bulunan ve kendilerine ait olan kullandıkları veya şu an kullanmadıkları ilaçları getirmeleri talep edildi ve ilaçları kullanma ile ilgili davranışları belirli sorularla irdelendi.

Bulgular: Kişilerin evlerinde kendilerine ait yaklaşık olarak ortalama 6 farklı etken maddeli ilaç (5.95 \pm 4.30 ) olduğu belirlendi. İlaçların \%64,9'unu düzenli olarak, \%21.3'ünü ara sıra kullanılmakta ve \%13.8'ini ise önceden kullanmış ancak şu anda kullanılmamakta olduğu saptandı. Düzenli olarak kullanılan, ara sıra kullanılan ve önceden kullanıımış olup şimdi kullanılmayan ilaç sayısı ortalaması ve standart sapması sırasıyla; $3.86 \pm 3.36,1.27 \pm 1.75$, $0.82 \pm 1.82$ 'dir. Polifarmasi (5 ve üzeri aktif olarak ilaç kullanma) sıklığı \%36.5'dir. Multivariate analiz sonuçlarına göre, kişide diyabet, hipertansiyon, solunum sistemi veya kardiyovasküler sistem (hipertansiyon dışı) hastalığı bulunması, görme bozukluğu yaşaması veya işitme rahatsızlığı bulunması toplam ilaç kullanımını anlamlı sekilde artırmış̧ı $(p<0.05)$.

Sonuç: Polifarmasiye yol açan asıl etkenin kronik hastalıklar ve kent merkezinde yaşam olduğu saptanmıştı; dolayısıyla kronik hastalıkların takibi ve azaltılmasına yönelik uygulamalar ve il merkezlerine akılcı ilaç kullanımı konusunda eğitim verilerek müdahale edilmesi gerekmektedir.

Anahtar sözcükler: Polifarmasi; Yaşlı; Kronik hastalık 


\section{INTRODUCTION}

The population over the age of 65 years has been growing rapidly as a result of the demographic transformation of the world and Turkey. The global elderly population, which was approximately 534 million in 2010, is estimated to be approximately 1.5 billion (mostly in developing countries) in 2050 (1).

In Turkey, the elderly population (age $\geq 65$ years) was 5,891,694 in 2013. In the last 5 years, it increased by $17 \%$ and reached 6,895,385 in 2017. The ratio between the elderly population and the total population was 7.7\% in 2013 and increased to $8.5 \%$ in 2017. Based on future population estimates by the Turkish Statistical Institute, the ratio of elderly population is expected to be $10.2 \%$ in $2023,12.9 \%$ in $2030,16.3 \%$ in $2040,22.6 \%$ in 2060 and $25.6 \%$ in 2080 (2).

Along with increase in the life expectancy, there have been changes in the causes of diseases and deaths. At the dawn of the 20th century, the major health threats were infectious and parasitic diseases that most often claimed the lives of infants and children. Currently, non-communicable diseases that more commonly affect adults and older people impose the greatest burden on global health. As a result, elderly people refer more to physicians due to increase in the number of elderly people with prolonged life expectancy, the multiplicity of comorbid diseases and increase in the need for health care. This may cause the elderly population to be in the forefront of drug consumption. The need for long-term use of drugs due to chronic diseases leads to concomitant use of certain drugs. Besides, undesirable side effects of drugs can easily occur owing to long-term use, drug-drug interactions and age-related changes in metabolic processes. For these reasons, the use of multiple drugs leads to a vicious circle that is difficult to break, if not prevented, in the elderly (3).

Polypharmacy (multi-drug use) has different definitions and can be expressed as the use of $\geq 4-5$ drugs per day, the use of drugs more than those that are clinically indicated and the use of at least one unnecessary drug (4). The incidence of polypharmacy increases with age and also varies among countries. Study in the United States of America (USA) report that $23 \%$ of women aged over 65 years living in the community and $35 \%-40 \%$ of those aged $75-85$ years have been shown to use $\geq 5$ drugs (5). In the United Kingdom, $36 \%$ of individuals aged over 75 years have been shown to use $\geq 4$ drugs per day (6). In Turkey, although there are no comprehensive data concerning the elderly living in the community, in studies among patients admitted to polyclinics, the rate of using $\geq 5$ drugs was found to be $63.2 \%$ for women and $55.3 \%$ for men aged over 65 years. According to this study, the average number of drugs used per person was 4.5 and the use of $\geq 10$ drugs was $7.9 \%$ (7).

The present study aimed to determine the frequency of polypharmacy and the risk factors in the elderly (aged $\geq 65$ years).

\section{MATERIALS AND METHOD}

This cross-sectional study will be analysed in three stages (polypharmacy, drug characteristics and drug interaction). Herein, the first stage (polypharmacy) was conducted at Burdur city centre and the connected villages. The study population comprised 11,360 subjects, after excluding individuals who are in prison (12 individuals) and those whose residence is outside the city centre (519 individuals) from 11,900 subjects aged $\geq 65$ years who were registered with 28 family physicians in Burdur city centre. Considering the population of 11,360 individuals, prevalence of $50 \%$, sampling error rate of 0.05 and confidence interval of $95.0 \%$, the minimum sample size, which represents the population in the Epi info programme, was calculated to be 378. A total of 400 subjects were decided to be included in the study. The subjects to be sampled were selected by listing them as those who are registered with 1 st family physicians to those who are registered with 28th family physicians (to protect regional factors as much as possible) using a systematic sampling method. A backup for each person was also identified. Because 13 individuals could not be reached, predefined back-ups were contacted. A pre-test was performed on 10 subjects (aged >65 years), who dropped out from the selected samples and back-ups selected before the research, and the questions were revised. The dependent variable of the study included 
the total number of different drugs used by the subjects, whereas the independent variables included the rational drug use, attitudes and behaviours of the elderly and the general socio-demographic variables. First, a questionnaire of 30 questions about sociodemographic variables and rational drug use was distributed among the subjects. Second, the subjects were asked to bring their own drugs from home that they were actively using or not currently using. Their drug-using behaviour was then analysed via specific questions. Before data collection, training was provided to midwives and nurses who would collect the data to fill the questionnaire in order to ensure standardisation. Home visits were conducted by community health centre midwives and nurses who had previously received training and had field experience, and face-to-face interviews and questionnaires were conducted for subjects who provided consent to participate in the survey. Survey forms were filled by midwives and nurses. Data were collected between May 2016 and June 2016, and the obtained data were recorded electronically for statistical analysis using SPSS 22.0 statistical analysis software (SPSS Inc. Chicago, IL, USA). Quantitative data were represented as arithmetic average and standard deviation, and count data were represented as number (percentage). The chi-square test and Student's t-test were used for the analysis of variables, and logistic regression (backward LR) was used for multivariate analysis. The results were evaluated using a 95\% confidence interval, and $p<0.05$ was considered statistically significant. Medical ethics committee approval was obtained from Başkent University Medical and Health Sciences (date: 17 May 2016, protocol number: KA16/215). After obtaining the necessary permits, the permission of Burdur Governorship Public Health Directorate was also obtained (date: 20 May 2016 and number of the permission file: 13124672/663.08), and the implementation of the research was started.

\section{RESULTS}

This study included a total of 400 subjects aged $\geq 65$ years, among which $64.0 \%$ lived in the city centre, $57.0 \%$ were women and $45.2 \%$ were aged $\geq 75$ years.
Furthermore, $64.2 \%$ of the subjects were married and $25.2 \%$ had no social security. Only $9.7 \%$ of the subjects graduated from secondary school and higher education institutions. During the study, subjects aged $>65$ years were asked to bring all their medications from home, and the medications were recorded according to their different types. A total of 2,378 different drugs were found to be possessed by the 400 subjects. The average number of different drugs possessed by the subjects at home was approximately 6 (5.95 \pm 4.30$)$. A total of $64.9 \%$ of the drugs were used regularly, $21.3 \%$ were used occasionally and $13.8 \%$ were previously used but not currently used. The median number \pm standard deviation of the drugs that were used regularly, occasionally used and previously used but not currently used was $3.86 \pm 3.36,1.27 \pm 1.75$ $0.82 \pm 1.82$, respectively. The frequency of polypharmacy (active use of $\geq 5$ drugs) was $36.5 \%$.

The results of univariate analysis performed to evaluate factors affecting polypharmacy in the elderly showed that the following were statistically significant risk factors responsible for increasing the frequency of polypharmacy: decreased number of people living in the house; female sex; age>75 years; those living in city centres; those who are widowed, single or separated; those living in nursing homes; diabetes; hypertension; heart problems; hearing problems; visual problems; chronic respiratory disorders; history of urinary incontinence and falling in the last 6 months and total number of illnesses and findings observed in the subject. The following factors did not have a statistically significant effect on polypharmacy in this age group: education status, presence of social security and income status, making the doctor prescribe medication without being sick, rheumatism, hernia, osteoarthritis and osteoporosis, gastrointestinal disorders, history of faecal incontinence, presence of disability report and nervous system disorders (Alzheimer, parkinson, vertigo, paralysis, etc.) (Table 1).

According to the results of multivariate analysis, the presence of diabetes, hypertension, respiratory system or cardiovascular system (except hypertension) diseases; visual impairment or hearing disorder significantly increased the total drug use $(p<0.05)$ (Table 2). 
Table 1. Effect of descriptive factors on polypharmacy.

\begin{tabular}{|c|c|c|c|c|}
\hline Characteristics & $\begin{array}{r}\text { Total } \\
(n=400 \\
|\% 100.0|)\end{array}$ & $\begin{array}{r}\text { Polypharmacy } \\
\text { is absent }(0-4 \\
\text { medications }) \\
(n=254|\% 63.5|) \\
\end{array}$ & $\begin{array}{r}\text { Polypharmacy } \\
\text { is present }(\geq 5 \\
\text { medications) } \\
(n=146|\% 36.5|) \\
\end{array}$ & $p$ \\
\hline Sex (Female) & $228(57.0)$ & $132(52.0)$ & $96(65.8)$ & 0.007 \\
\hline Age (years $\mid$ mean \pm sd) & $74.5 \pm 6.8$ & $73.9 \pm 6.8$ & $75.6 \pm 6.7$ & 0.017 \\
\hline Living place (city centre) & $256(64.0)$ & $150(59.1)$ & $106(72.6)$ & 0.007 \\
\hline Marital status (married) & $257(64.3)$ & $177(69.7)$ & $80(54.8)$ & 0.003 \\
\hline $\begin{array}{l}\begin{array}{l}\text { Education status } \\
\text { Illiterate } \\
\text { Secondary school graduate and higher } \\
\text { Literate } \\
\text { Senary school graduate }\end{array}\end{array}$ & $\begin{array}{r}78(19.5) \\
49(12.3) \\
234(58.5) \\
39(9.7)\end{array}$ & $\begin{array}{r}44(17.3) \\
29(11.4) \\
158(62.2) \\
23(9.1)\end{array}$ & $\begin{array}{l}34(23.3) \\
20(13.7) \\
76(52.1) \\
16(11.0)\end{array}$ & 0.255 \\
\hline Has social security & $299(74.8)$ & $194(76.4)$ & $105(71,9)$ & 0.323 \\
\hline $\begin{array}{r}\text { Not enough } \\
\text { Barely enough } \\
\text { Easily earn a livelihood }\end{array}$ & $\begin{array}{r}89(22.3) \\
187(46.8) \\
124(31.0)\end{array}$ & $\begin{array}{r}52(20.5) \\
120(47.2) \\
82(32.3)\end{array}$ & $\begin{array}{l}37(25.3) \\
67(45.9) \\
42(28.8)\end{array}$ & 0.498 \\
\hline $\begin{array}{r}\text { Only partner } \\
\text { Partner and relatives* } \\
\text { Only relatives } \\
\text { Alone } \\
\text { Nursing home } \\
\end{array}$ & \begin{tabular}{r|}
$206(51.5)$ \\
$51(12.8)$ \\
$54(13.5)$ \\
$72(18.0)$ \\
$17(4.2)$
\end{tabular} & $\begin{array}{r}142(55.9) \\
35(13.8) \\
32(12.6) \\
38(15.0) \\
7(2.8)\end{array}$ & $\begin{array}{r}64(43.8) \\
16(11.0) \\
22(15.1) \\
34(23.3) \\
10(6.8)\end{array}$ & 0.028 \\
\hline The number of people living at home (mean \pm sd) & $2.2 \pm 1.2$ & $2.3 \pm 1.2$ & $2.1 \pm 1.1$ & 0.044 \\
\hline $\begin{array}{l}\text { Making the doctor prescribe medication without } \\
\text { being sick }\end{array}$ & $174(43,5)$ & $114(44.9)$ & $60(41.1)$ & 0.462 \\
\hline Diabetes & $82(20.5)$ & $30(11.8)$ & $52(35.6)$ & $<0.001$ \\
\hline Hypertension & $201(50.3)$ & $97(38.2)$ & $104(71.2)$ & $<0.001$ \\
\hline Cardiovascular disease (except hypertension) & $123(30.8)$ & $42(16.5)$ & $81(55.5)$ & 0.000 \\
\hline Cancer & $7(1.8)$ & $3(1.2)$ & $4(2.7)$ & 0.264 \\
\hline Vision impairment & $305(76.2)$ & $188(74.0)$ & $117(80.1)$ & $<0.001$ \\
\hline Hearing problem & $166(41.5)$ & $87(34.3)$ & $79(54.1)$ & $<0.001$ \\
\hline Respiratory tract disorders & $46(11.5)$ & $19(7.5)$ & $27(18.5)$ & 0.001 \\
\hline $\begin{array}{l}\text { Rheumatism, herniated disc, osteoarthritis and } \\
\text { osteoporosis }\end{array}$ & $122(20.5)$ & $82(32.3)$ & $40(27.4)$ & 0.307 \\
\hline Gastrointestinal tract disorders & $46(11.5)$ & $27(10.6)$ & $19(13.0)$ & 0.472 \\
\hline $\begin{array}{l}\text { Nervous system disorders (Alzheimer, Parkinson, } \\
\text { vertigo, paralysis, etc.) }\end{array}$ & $47(11.8)$ & $28(11.0)$ & $19(13.0)$ & 0.552 \\
\hline Stroke history & $56(14.0)$ & $28(11.0)$ & $28(19.2)$ & 0.024 \\
\hline Stress incontinence & $155(38.8)$ & $81(31.9)$ & $74(50.7)$ & $<0.001$ \\
\hline Urge incontinence & $168(42.0)$ & $93(36.6)$ & $75(51.4)$ & 0.004 \\
\hline Faecal incontinence & $27(6.8)$ & $16(6.3)$ & $11(7.5)$ & 0.636 \\
\hline Fall in last 6 months & $95(23.8)$ & $52(20.5)$ & $43(29.5)$ & 0.042 \\
\hline Disability reports & $5(1.2)$ & $1(0.4)$ & $4(2.7)$ & 0.062 \\
\hline $\begin{array}{l}\text { Total number of illnesses and findings in the per- } \\
\text { son (mean } \pm \text { sd) }\end{array}$ & $3.8 \pm 1.9$ & $3.2 \pm 1.8$ & $4.9 \pm 1.5$ & $<0.001$ \\
\hline
\end{tabular}

*** Do you ask your doctor to prescribe medication without being sick or do you buy it and keep it at home thinking it might be necessary?

* Relatives: children, grandchildren and other people. 
Table 2. Factors affecting polypharmacy.

\begin{tabular}{|l|r|r|}
\hline Factor & OR (95\%, Cl) & p \\
\hline Living place (province centre, village ref.) & $1.816(1.054-3.130)$ & 0.032 \\
Diabetes (present, absent ref.) & $3.239(1.800-5.828)$ & $<0.001$ \\
Hypertension (present, absent ref.) & $2.689(1.621-4.460)$ & $<0.001$ \\
Cardiovascular (except hypertension) diseases (present, absent & $4.923(2.928-8.277)$ & $<0.001$ \\
ref.) & $2.226(1.409-3.873)$ & 0.001 \\
Hearing problem (present, absent ref.) & $2.934(1.407-6.120)$ & 0.004 \\
Chronic respiratory disorder (present, absent ref.) & \\
\hline Backward LR logistic regression, -2Log likelihood: 370.543, Nagelkerke R Square: 0.438, variables in the equation: \\
p=0.000, wald: 28.426. \\
OR: odds ratio; Cl: confidence interval
\end{tabular}

\section{DISCUSSION}

In our study group, the frequency of polypharmacy (active use of $\geq 5$ drugs) was $36.5 \%$, which was considered as a significant problem. The incidence of polypharmacy increases with age and varies between countries, and it is reported to be approximately $35 \%-40 \%$ in the elderly aged $>75$ years $(8,9)$. The frequency of polypharmacy also varies between the elderly living in the community and the elderly living in the nursing home. Among the patients living in the community, the incidence rates of $41 \%, 43.4 \%, 35.8 \%$ and $46.8 \%$ were reported from Iceland, USA, Australia and Italy, respectively (10-12). In a recent study conducted among nursing homes as a report of shelter work in eight European countries, the incidence rate was reported to be $49.7 \%$ (13). In the study conducted by Arslan et al., it was found that $28.2 \%$ of the participants were using one drug, $24.3 \%$ two drugs, $18.5 \%$ three drugs, $11.7 \%$ four drugs and $17.3 \%$ five or more drugs (14). Gurol Arslan et al. revealed that $35 \%$ of the elderly were using 5-6 drugs and the number of drugs used by them was $4.5 \pm 1.8$ (15). In the study conducted by Kutsal et al. in 2006 on multiple drug use by interviewing 1,433 elderly aged $\geq 65$ years, $84.7 \%$ of the elderly who participated in the survey had at least one drug that was regularly used and $15.3 \%$ did not have any; furthermore, 23.2\% of the subjects stated that they were using only one drug, 17\% two drugs, $19.2 \%$ three drugs and $38.2 \%$ four and more drugs (16). In the study by Arslan et al. (15) evaluating drug use in patients aged $\geq 65$ years, there was no significant difference between male and female patients in terms of the amount of drugs used; $11.7 \%$ of the elderly were using four drugs and $17.3 \%$ were using five or more drugs. The results of univariate analysis showed that polypharmacy was more common in women. Based on the results of multivariate analysis, it was found that the presence of chronic diseases in general was the main risk factor. Longer life expectancy and higher frequency of chronic illness in women, especially those aged $>65$ years, were risk factors for using multiple drugs. There are many factors driving polypharmacy. Some studies have shown a relationship between polypharmacy and both female sex and age $>80$ years $(17,18)$. In our study, there was no relationship between socio-demographic factors and polypharmacy. This may have been due to the characteristics of the study group.

As a general outcome of the study, the presence of chronic diseases that increase with age leads to polypharmacy. Because chronic diseases, 
especially hypertension, is both frequent and leads to the use of multiple drugs in the relevant age group, it is considered an important problem that needs to be addressed. Approximately half of those participating in the study and $71.2 \%$ of those with polypharmacy have hypertension. In the study by Ozturk et al. evaluating the drug use in patients aged $>65$ years, the amount of subjects using four and more drugs was $46.7 \%$ and similarly the frequency of hypertension was $48.1 \%$ (19). In the study conducted by Iscigil et al., in which the elderly living in nursing homes and patients who applied to university polyclinics were studied and compared based on their drug use, antihypertensives were reported as the most commonly used drugs (20). Ozturk et al. also found that the frequency of hypertension was high (approximately 50\%) in the elderly, and it was one of the significant risk factors of polypharmacy (21). Diabetes, one of the chronic diseases, also emerged as a significant public health problem with a frequency of $20.5 \%$ in the study group. In addition, approximately $35 \%$ of those who used multiple drugs and $11.8 \%$ of those who did not use any drugs had diabetes. In our study, diabetes was considered to be another significant risk factor of polypharmacy. Similarly, in the study by Ozturk et al., the frequency of diabetes was found to be $23.2 \%$ in the elderly (19). Arslan et al. found that the frequency of diabetes was $10.2 \%$ in the elderly living in the nursing home (15). In the study by Oztürk et al. examining the factors affecting polypharmacy in the elderly, the frequency of diabetes was found to be $39.0 \%$ in the study group, $49.0 \%$ in the polypharmacy group and $24.0 \%$ in the non-polypharmacy group (21). It is understood that diabetes is one of the major disease groups, which requires intervention, in terms of rational drug use. In other foreign studies, similarly to our study, it has been found that diabetes and hypertension lead to polypharmacy (22-23). In our study, the number of elderly people with hearing impairment, which was diagnosed based on the Problems and Expectations of People with Disabilities study (2010), was found to be significantly higher than that of people aged $\geq 65$ years (7.7\%) (24). This difference is considered to be attributed to the fact that those with mild hearing loss, who do not require hearing aids, were also included in our study as those with hearing problems. Hearing problems can also trigger polypharmacy as it appears with other chronic diseases. Another factor affecting polypharmacy was chronic respiratory diseases; $11.5 \%$ of the study group and $18.5 \%$ of those with polypharmacy had chronic respiratory disease. In patients with such chronic conditions, the problem of multiple and long-term drug use is prevalent.

In our study, polypharmacy was found to be higher in subjects who live in the city centre. Studies have shown that elderly people living in urban areas have more tendency toward polypharmacy due to the following: the ease of access to health services, the tendency of patients to visit different doctors and take many prescriptions, the presence of excess drug expectations, the use of medication for symptoms rather than diagnosis, the tendency of doctors to terminate current medication and start a new one, the large number of non-prescription drug sales without awareness of the physicians and the tendency of elderly patients to use medications taken from family members or surroundings (25). Doctor or Physicians; which one?

In conclusion, the prevention of chronic diseases, which is considered as the main cause of polypharmacy in the elderly, the adaptation of a rational drug use approach by physicians and the follow-up and regulation of drugs by family physicians, especially for the elderly with chronic diseases, are shown to be necessary to maintain multiple drug use at a certain level. We recommend trainings on rational drug use in city centres and then in rural areas and preventing patients from taking drugs from pharmacies in an uncontrolled manner. 


\section{REFERENCES}

1. Arslan S, Atalay A, Gokce Kutsal Y. Drug use in older people. J Am Geriatr Soc 2002;50(6):1163-4. (PMID:12110084).

2. Badedi M, Solan Y, Darraj H, et al. Factors associated with long-term control of type 2 diabetes mellitus. J Diabetes Res 2016;2109542. (PMID:28090538).

3. Bahat G, Tufan F, Bahat Z, et al. Comorbidities, polypharmacy, functionality and nutritional status in Turkish community-dwelling female elderly. Aging Clin Exp Res 2014;26:255-9. (PMID:24781830).

4. Ballentine HN. Polypharmacy in the elderly. Critical Care Nursing Quarterly 2008; 31: 4. (PMID:18316935).

5. Beer C, Hyde Z, Almeida OP, et al. Quality use of medicines and health outcomes among a cohort of community dwelling older men. J Clin Pharmacol 2011;71:592-9. (PMID:21395652).

6. Discigil G, Tekinc N, Anadol Z, Bozkaya AO. Polypharmacy in nursing home and communitydwelling elderly. Turk J Geriatrics 2006;9:117-21. (in Turkish)

7. Gokce Kutsal Y, Barak A, Atalay A, et al. Polypharmacy in the elderly: A multicenter study". J Am Med Dir 2009;1(7):486-90. (PMID:19716065).

8. Gürol AG, Eşer i. Self-medication compliance in elderly and nurses role. Journal of Ege University Nursing Faculty 2005;21:147-57. (in Turkish).

9. Heuberger RA, Caudell K. Polypharmacy and nutritional status in older adults. Drugs Aging 2011;28:315-23. (PMID:21428466).

10. Kaufman DW, Kelly JP, Rosenberg L, Anderson TE, Mitchell AA. Recent patterns of medication use in the ambulatory adult population of the United States: The Slone Survey. JAMA 2002;287:337- 44. (PMID:11790213)

11. Mamun K, Lien CTC, Goh-Tan CYE. Polypharmacy and inappropriate medication use in Singapore nursing homes. Ann Acad Med Singapore 2004; 33:49-52. (PMID:15008562).

12. McCracken R, McCormack J, McGregor MJ, Wong ST, Garrison S. Associations between polypharmacy and treatment intensity for hypertension and diabetes: a cross-sectional study of nursing home patients in British Columbia, Canada. BMJ Open 2017;7(8):7-8. (PMID:28801438).

13. Morin L, Johnell K, Laroche ML, Fastbom J, Wastesson JV. The epidemiology of polypharmacy in older adults: register-based prospective cohort study. Clin Epidemiol 2018;10:289-98. (PMID:29559811).
14. Onder G, Liperoti R, Fialova D, et al. Polypharmacy in nursing home in Europe: results from the Shelter study. J Gerontol A Biol Sci Med Sci 2012;67(6):698704. (PMID:22219520).

15. Ozturk Z, Ugras KG. Drug use and polypharmacy in elderly patients. The Journal of Tepecik Education and Research Hospital 2017;27(2):103-08.

16. Ozturk ZG, Ardic C, Toprak D. Frequency of polypharmacy and use of potentially inappropriate Medications in the elderly. Turk J Geriatrics 2017;20(4):296-305. (PMID:127620431)

17. Pereira KG, Peres MA, lop $D$, et al. Rev Bras Epidemiol 2017;20(2):335-44. (PMID:28832855).

18. Prescribing and Medicines Team Health and Social Care Information Centre. Prescriptions dispensed in community statistics for 1989-1999: England. Statistical Bulletin 2014. [Internet] Available from: https://digital.nhs.uk/data-and-information/ publications/statistical/prescriptions-dispensed-inthe-community. Accessed: 05.02.2018.

19. Qato DM, Alexander GC, Conti RM, et al. Use of prescription and over-the-counter medications and dietary supplements among older adults in the United States. JAMA 2008;300:2867-78. (PMID:19109115).

20. Rochon PA, Schmader KE, Sokol HN. Drug prescribing for older adults. [Internet] Available from: https://www.uptodate.com/contents/drugprescribing-for-older-adults. Accessed: 14.04.2018.

21. Santos TRA, Lima DM, Nakatani AYK, et al. Medicine use by the elderly in Goiania. Midwestern Brazil 2013;47(1):94-103. (PMID:23703135).

22. Sigurdardottir AK, Arnadottir SA, Gunnarsdottir ED. Medication use among community-dwelling older Icelanders. Laeknabladid 2011;97:675-80. (PMID:22133526).

23. TurkStat, Statistics by the Aged 2017, Number: 27595, [Internet] Available from: http://www.tuik. gov.tr/PreHaberBultenleri.do?id=27595, Accessed: 15.03.2018.

24. TurkStat, Survey on Problems and Expectations of Disabled People, 2010 [Internet] Available from: www.tuik.gov.tr/lcerikGetir.do?istab_id=244. Accessed: 26.6.2018.

25. United Nations. World Population Prospects: The 2010 Revision. [Internet] Available from: http://esa. un.org/unpd/wpp. Accessed: 26.7.2018. 